\title{
ETNISITAS DAN AGAMA DI KOTA SURABAYA: INTERAKSI MASYARAKAT KOTA DALAM PERSPEKTIF INTERAKSIONISME SIMBOLIK
}

\author{
Etnicity and Religion in Surabaya: Interaction of City Community \\ in Symbolic Interactionism Perspective
}

\author{
Ujianto Singgih Prayitno* dan Purnawan Basundoro** \\ *Pusat Pengkajian, Pengolahan Data dan Informasi (P3DI) \\ Sekretariat Jenderal DPR RI \\ **Universitas Airlangga Surabaya
}

Naskah diterima: 17 September 2015

Naskah dikoreksi: 20 November 2015

Naskah diterbitkan: 23 Desember 2015

\begin{abstract}
This research is motivated by the emergence of various conflicts in various cities in Indonesia which is triggered by the activation of ethnicity and religious stereotypes, either individually or in groups in their social interaction. Surabaya is one of the big cities inhabited by various ethnic and religious and those are potential to cause conflict. This study attempts to highlight how the picture of the interaction and the level of trust among ethnic and religious in the city of Surabaya. This study is expected to provide an overview of vertices that have the potential to create conflicts in the future so that it can be anticipated by the Government. Using qualitative method and symbolic interactionism approach, which assumes that the social reality is a series of events that occur in some individuals in the society and lasted consciously and it is related to gestures, vocal, voice, and body expression, it is concluded that the city is a melting pot where people of various ethnic groups and religions merge into one. The conflict occurred because of the characteristics of the groups in conflict distinguishable in the clarity of boundaries between groups in conflict; and the degree of organization of each group are closely related to patterns of interaction and communication that was developed from two sides.
\end{abstract}

Keywords: Etnicity, religion, social interaction, symbolic interactionism.

\begin{abstract}
Abstrak. Penelitian ini dilatarbelakangi oleh munculnya beragam konflik di berbagai kota di Indonesia yang dipicu oleh aktivasi stereotip etnisitas dan keagamaan baik itu secara individu maupun kelompok dalam interaksi sosial mereka. Surabaya adalah salah satu kota besar yang dihuni oleh berbagai etnik dan agama yang berpotensi memunculkan konflik. Penelitian ini mencoba menyoroti gambaran interaksi dan tingkat kepercayaan antaretnik dan agama di Kota Surabaya. Penelitian ini diharapkan memberikan gambaran simpul-simpul yang berpotensi memunculkan konflik di masa depan sehingga dapat diantisipasi oleh Pemerintah. Dengan menggunakan metode kualitatif dan pendekatan interaksionisme simbolik, yang mengasumsikan bahwa realitas sosial merupakan rangkaian peristiwa yang terjadi pada beberapa individu dalam masyarakat dan berlangsung secara sadar dan berkaitan dengan gerak tubuh, vokal, suara, dan ekspresi tubuh, menyimpulkan bahwa kota adalah melting pot tempat orang dari berbagai macam etnis dan agama melebur menjadi satu. Konflik terjadi karena karakteristik kelompok-kelompok yang berkonflik terbedakan dalam kejelasan batas-batas antara kelompok-kelompok yang berkonflik; dan derajat pengorganisasian masing-masing kelompok yang erat kaitannya dengan pola interaksi dan komunikasi yang dikembangkan dari dua belah pihak.
\end{abstract}

Kata kunci: Etnisitas, agama, interaksi sosial, interaksionisme simbolik.

\section{Pendahuluan}

Individu merupakan hal yang penting dalam konsep sosiologi, sebagai obyek yang bisa secara langsung ditelaah dan dianalisis melalui interaksinya dengan individu yang lain. Dalam perspektif ini dikenal nama sosiolog George Herbert Mead (1863-1931), Charles Horton Cooley (1846-1929), yang memusatkan perhatiannya pada interaksi antara individu dan kelompok. Mereka menemukan bahwa individu-individu tersebut berinteraksi dengan menggunakan simbol-simbol, yang di dalamnya berisi tanda-tanda, isyarat, dan kata-kata. Sosiolog interaksionisme simbolik kontemporer lainnya adalah Herbert Blumer (1962) dan Erving Goffman (1959). Interaksionisme simbolik memfokuskan diri pada hakekat interaksi, pada pola-pola dinamis dari tindakan sosial dan hubungan sosial. 
Interaksi individu dalam masyarakat antara lain termanifestasi dalam hubungan antarumat beragama, sebagai proses sosial yang muncul dalam proses pengalaman dan aktivitas sosial. Dalam interaksi ini dimediasi oleh penggunaan simbol-simbol, oleh interpretasi, atau oleh penetapan makna dari tindakan orang lain. Semua interaksi antarindividu manusia melibatkan suatu pertukaran simbol. Ketika antarumat beragama saling berinteraksi, biasanya secara konstan mereka mencari "petunjuk" mengenai tipe perilaku apakah yang cocok dalam konteks itu dan mengenai bagaimana menginterpretasikan apa yang dimaksudkan oleh orang lain.

Dalam interaksi sosial itu, agama bukanlah satusatunya hal yang mendasari hubungan, tetapi juga etnisitas. Agama dan etnisitas merupakan dua aspek penting yang memengaruhi dinamika hubungan sosial di Indonesia. Berbagai konflik pascaruntuhnya Orde Baru yang menyebabkan puluhan ribu jiwa meninggal melibatkan unsur agama dan atau etnis. Keterlibatan etnis Madura dan Dayak di Kalimantan Barat, Muslim dan Kristen di Maluku dan Poso adalah di antara sejarah kelam hubungan sosial yang kental dengan semangat etnisitas dan agama, bahkan dewasa ini konflik antarpemeluk agama yang samapun telah sering terjadi, seperti konflik suni dan syiah di Madura. Peristiwa ini, jelas telah merusak mozaik sosial budaya Indonesia, terutama bagian Timur yang telah dimanipulasi oleh berbagai pihak. Kondisi dan situasi ini menjebak mereka dalam situasi yang terpinggirkan dan akibat berikutnya, konflik komunal antarmereka makin keras dan berkelanjutan.

Kondisi tersebut memperlihatkan dengan jelas adanya "disintegrasi sosial" yang menyangkut hilangnya insting komunitas secara meluas, yaitu dari hilangnya rasa memiliki sekelompok orang terhadap sebuah negara bangsa, hilangnya ikatan atau solidaritas komunal, hingga hilangnya ketaatan pada sistem sosial dan normatif yang berlaku. Proses disintegrasi struktural ini mengakibatkan gagalnya proses disintegrasi setiap kelompok masyarakat dalam suatu sistem akses dan kontrol, integrasi ke dalam sistem general sejalan dengan kepentingan umum yang ingin dicapai, integrasi dalam sistem hukum dan perundang-undangan, dan integrasi fungsional ke dalam fungsi-fungsi yang harus diwujudkan. Proses disintegrasi semacam ini akan memengaruhi masyarakat dalam merespon berbagai tantangan dan peluang ke depan.

Indonesia adalah negara yang masyarakatnya bersifat majemuk dan potensial untuk memunculkan kebangkitan kesadaran etnik dan penguatan eksklusivisme agama, yang dapat memicu pertentangan antarkelompok. Dampak yang paling nyata adalah munculnya masyarakat yang terbelah dalam berbagai ikatan-ikatan primodial. Persoalan para penganut agama dan etnisitas kedaerahan tidak dapat dihapus dari agenda pemerintahan. Kebangkitan kesadaran etnik yang meningkatkan intensitas dan kualitas gerakan-gerakan sosioetnik maupun keagamaan merupakan suatu reaksi logis dan tidak terhindarkan dari suatu upaya mempertahankan diri terhadap struktur lingkungan eksternal yang tidak menguntungkan atau bahkan mengancam keberadaan suatu kelompok etnik. Namun, pada kenyataannya sulit untuk menentukan sumber-sumber menguatnya kesadaran etnik.

Secara umum, permasalahan yang masih dihadapi yang dapat memunculkan persoalan etnisitas dan agama, antara lain adalah: (1) pembangunan yang belum diimbangi dengan pembangunan karakter bangsa yang mengakibatkan terjadinya krisis budaya yang dapat memperlemah jati diri bangsa (nasional); (2) kemampuan bangsa dalam mengelola keragaman etnik dan agama belum optimal yang ditandai oleh: (a) adanya disorientasi tata nilai, seperti nilai solidaritas sosial, kekeluargaan, dan keramahtamahan sosial; dan (b) adanya kecenderungan pengalihan ruang publik ke ruang privat mengakibatkan terbatasnya tempat penyaluran aspirasi masyarakat multikultur; (3) identitas nasional mengalami penurunan, yang ditandai oleh: (a) belum memadainya pembentukan sikap moral dan penanaman nilai budaya dan agama yang mengakibatkan adanya kecenderungan semakin menguatnya nilai-nilai materialisme; dan (b) kemampuan masyarakat dalam menyeleksi nilai dan budaya global masih terbatas sehingga terjadi pengikisan nilai-nilai budaya nasional yang positif (Biro PUU Sekjen DPR RI, 2009). Oleh karena itu, pertanyaan dalam penelitian ini adalah bagaimana interaksi antar etnik dan agama di Kota Surabaya terjadi dan bagaimana kepercayaan antaretnik dan agama dalam interaksi sosial tersebut?

Metode kualitatif dalam penelitian ini menggunakan pendekatan interaksionisme simbolik yang berpandangan bahwa kenyataan sosial sesungguhnya merupakan susunan lambanglambang yang menyembunyikan makna-makna dibaliknya. Realitas sosial merupakan rangkaian peristiwa yang terjadi pada beberapa individu dalam masyarakat. Interaksi yang dilakukan antarindividu itu berlangsung secara sadar dan berkaitan dengan gerak tubuh, vokal, suara, dan ekspresi tubuh, yang kesemuanya itu mempunyai maksud dan disebut dengan "simbol". Dalam kaitan ini Blumer (1962) meyakini bahwa studi manusia tidak dapat diselenggarakan dalam cara yang sama dengan studi 
tentang benda mati. Peneliti perlu mencoba empati dengan pokok materi, termasuk pengalamannya, dan usaha untuk memahami nilai dari tiap orang. Blumer dan pengikutnya menghindari pendekatan kuantitatif dan lebih menekankan riwayat hidup, autobiografi, studi kasus, buku harian, surat, dan wawancara tidak langsung.

\section{Perspektif Interaksionisme Simbolik ${ }^{1}$}

Inti pandangan pendekatan

teori interaksionisme simbolik ini adalah individu sebagai suatu hal yang paling penting dalam konsep sosiologi, sebagai obyek yang bisa secara langsung ditelaah dan dianalisis melalui interaksinya dengan individu yang lain. Interaksi manusia dimediasi oleh penggunaan simbol-simbol, oleh interpretasi, atau oleh penetapan makna dari tindakan orang lain yang ekuivalen dengan pelibatan proses interpretasi antara stimulus dan respon dalam kasus perilaku manusia. (Prayitno, 2011) Pendekatan interaksionisme simbolik memberikan banyak penekanan pada individu yang aktif dan kreatif dibandingkan dengan pendekatan-pendekatan teoritis lainnya. Gagasan teori interaksionisme simbolik menjadi sebuah label untuk sebuah pendekatan yang relatif khusus pada ilmu dari kehidupan kelompok manusia dan tingkah laku manusia. Banyak ilmuwan yang telah menggunakan pendekatan ini dan memberikan kontribusi intelektualnya, di antaranya George Herbert Mead, John Dewey, W.I Thomas, Robert E.Park, William James, Charles Horton Cooley, Florian Znaniceki, James Mark Baldwin, Robert Redfield dan Louis Wirth.

Ritzer dan Goodman (2004) dalam bukunya yang bertajuk, Sociological Theory, menjelaskan, bahwa interaksionisme simbolik pada hakikatnya merupakan sebuah perspektif yang bersifat sosialpsikologis yang relevan untuk penelitian sosiologi. Teori ini sangat berkaitan dengan struktur-struktur

Akar tertua teori interaksionisme simbolik adalah paradigma definisi sosial yang dikembangkan oleh Max Weber, seorang sosiolog berkebangsaan Jerman. Bagi Weber, sosiologi adalah ilmu sosial yang bersifat interpretative, yaitu ilmu pengetahuan yang menyelidiki makna-makna subyektif dari sebuah proses interaksi sosial timbal balik untuk memahami implikasi-implikasi yang dilahirkannya. Pemahaman ini, memunculkan anggapan, bahwa ilmu sosiologi yang dikembangkan oleh Weber dikenal dengan sosiologi subyektif, artinya, bagi Weber ilmu sosiologi menunjukkan obyek penyelidikan yang berhubungan dengan konstruksi makna-makna sosial sebagai sebuah kenyataan sosial tersendiri, yaitu maknamakna subyektif yang lahir sebagai hasil dialektika antara diri dan kenyataan eksternal. Kenyataan sosial tidak semata berada di luar kesadaran manusia, namun mengendap dalam struktur kesadaran subyektif manusia dan memengaruhi dirinya dalam berperilaku. sosial, bentuk-bentuk kongkret dari perilaku individual atau sifat-sifat batin yang bersifat dugaan, karena interaksionisme simbolik memfokuskan diri pada hakekat interaksi, pada pola-pola dinamis dari tindakan sosial dan hubungan sosial. Interaksi sendiri dianggap sebagai unit analisis, manusia dan struktur sosial dikonseptualisasikan secara lebih kompleks, lebih tak terduga, dan aktif jika dibandingkan dengan perspektifperspektif sosiologis yang konvensional. Di sisi ini masyarakat tersusun dari individu-individu yang berinteraksi yang tidak hanya bereaksi, namun juga menangkap, menginterpretasi, bertindak, dan mencipta. Individu bukanlah sekelompok sifat, namun merupakan seorang aktor yang dinamis dan berubah, yang selalu berada dalam proses menjadi dan tak pernah selesai terbentuk sepenuhnya.

Teori interaksionisme simbolik adalah salah satu cabang dalam teori sosiologi yang mengemukakan tentang diri sendiri (the self) dan dunia luarnya, yang dalam istilah Cooley disebut sebagai looking glass self (Kamanto, 2004). Pendekatan interaksionisme simbolik menganggap bahwa segala sesuatu tersebut adalah virtual, karena melibatkan suatu pertukaran simbol. Pada saat seseorang berinteraksi dengan yang lainnya, secara konstan akan mencari "petunjuk" mengenai tipe perilaku yang cocok dalam konteks itu, dan mengenai interpretasinya terhadap apa yang dimaksudkan oleh orang lain. Artinya interaksionisme simbolik mengarahkan perhatian pada interaksi antarindividu, dan bagaimana hal ini bisa dipergunakan untuk mengerti apa yang orang lain katakan dan lakukan sebagai individu.

Pada awal perkembangannya, teori interaksionisme simbolik dikembangkan oleh kelompok The Chicago School dengan tokohtokohnya seperti Goerge H. Mead dan Herbert Blummer. George Herbert Mead (1863-1931), ${ }^{2}$ menjelaskan bahwa interaksionisme simbolik merupakan teori studi perilaku individu dan atau kelompok kecil masyarakat melalui serangkaian pengamatan dan deskripsi (Prayitno, 2011). Metode ini berlandaskan pada pengamatan atas apa yang diekspresikan orang yang mencakup penampilannya, gerak-geriknya, dan bahasa simbolik yang muncul dalam situasi sosialnya. Interaksionisme simbolik memiliki cara pandang terhadap masyarakat dari bawah, sebagaimana situasi yang diciptakan oleh individu-individu. Melalui pendekatan ini, Mead dikenal juga sebagai seorang psikolog sosial, karena

Mead dikenal sebagai seorang sosiolog pragmatis, yang berkeyakinan bahwa semua teori sosial yang ada harus dapat diuji secara praktis, termasuk semua hal tentang kebenaran, pengetahuan, moralitas, dan politik. 
memang pada akhirnya ia banyak berbicara tentang proses berfikir, konsep diri dalam organisasi sosial, dan pola-pola pengambilan peran orang lain sebagai dasar organisasi sosial.

Lebih lanjut, teori sosial ini dikembangkan oleh Charles Horton Cooley (1864-1929), seorang sosiolog Amerika yang pernah dekat dengan Mead. Cooley membangun teori relasi sosial yang tidak bertitik berat pada kondisi individual maupun sosial, namun meyakini bahwa kedua hal itu tak bisa dipisah-pisahkan. Cooley banyak berbicara tentang konsep diri, yang disebutnya sebagai konsep "bercermin," sifat-sifat manusia, kelompok primer dalam pembentukan sifat manusia, interaksi antara pemimpin politik dan massanya, dan pentingnya arti sosial dalam nilai keuangan. Satu hal menarik yang ditunjukkan oleh Cooley adalah perumpamaannya yang mengatakan, bahwa sebuah kapal yang dibangun oleh seratus orang yang berbeda, sangat berbeda dengan seratus kapal yang masing-masing dibangun oleh satu orang, untuk menjelaskan terjadinya pandangan umum dalam masyarakat yang dibentuk oleh pandanganpandangan umum yang dimiliki oleh tiap individu yang membangun masyarakat.

Pemikiran sosial Cooley terdiri atas dua asumsi yang mendalam mengenai hakikat kehidupan sosial, yaitu bahwa kehidupan sosial secara fundamental merupakan sebuah evolusi organik, dan bahwa masyarakat itu secara ideal bersifat demokratis, moral, dan progresif (Prayitno, 2011). Konsep evolusi organik Cooley ini berbeda secara substansial dari konsep Spencer dan para ilmuwan sosial abad kesembilanbelas lainya. Cooley berusaha membangun sebuah pemahaman yang lebih mendalam mengenai individu, tetapi bukan sebagai entitas yang terpisah dari masyarakat, namun sebagai sebuah bagian psiko-sosial dan historis dari bahanbahan penyusun masyarakat. Jika pengetahuan yang riil atas diri individu akan dibangun, maka kita harus memandang individu secara keseluruhan, sebaliknya, jika melihatnya secara terpisah, maka proses pengetahuan atas diri individu akan gagal. Jadi, menurut Cooley, tugas fundamental dari sosiologi adalah untuk memahami sifat organis dari masyarakat sebagaimana berlangsung melalui persepsi-persepsi individual dari orang lain dan dari diri mereka sendiri.

Jika sosiologi hendak memahami masyarakat, dia harus mengkonsentrasikan perhatiannya pada aktivitas-aktivitas mental dari individu-individu yang menyusun masyarakat tersebut. Dalam konsep The Looking-Glass Self(Diri yang Seperti Cermin Pantul), menurut Cooley, institusi-institusi sosial yang utama ialah bahasa, keluarga, industri, pendidikan, agama, dan hukum. Sementara institusi-institusi tersebut membentuk 'fakta-fakta dari masyarakat' yang bisa dipelajari oleh studi sosiologi, mereka juga merupakan produk-produk yang ditentukan dan dibangun oleh pikiran publik. Menurut Cooley, institusi-institusi tersebut merupakan hasil dari organisasi dan kristalisasi dari pikiran yang membentuk adat-adat kebiasaan, simbol-simbol, kepercayaan-kepercayaan, dan sentimen-sentimen perasaan yang tahan lama.

\section{Kompleksitas Etnis}

Sebuah bangsa memang akan selalu mengalami tahapan dalam sejarah kebangsaannya. Braudel dalam Suparlan, (2008), menyatakan bahwa rentang panjang sejarah tertentu berperan dalam membentuk karakter manusia dan secara mendasar akan memperlihatkan sifat-sifat dasar dan kecenderungan ideologis dan politis dalam merespons kondisi alam dan sosial budaya sekelilingnya. Proses pemberdayaan masyarakat dengan rentang yang panjang ini terjadi dalam jaringan sosial. Jaringan (Fukuyama, 2000:327) merupakan hubungan moral kepercayaan, yaitu sekelompok agen-agen individual yang berbagi normanorma atau nilai-nilai informal melampaui nilai-nilai atau norma-norma yang penting dalam kehidupan bermasyarakat. Kehidupan bermasyarakat, dengan demikian, memberikan pengakuan kepada kelompokkelompok etnik dan agama agar dapat memposisikan dirinya ke dalam sebuah kehidupan bersama yang memiliki kesanggupan untuk memelihara identitas kelompoknya. Di samping itu, juga mampu berinteraksi dalam ruang bersama yang ditandai oleh kesediaan untuk menerima kelompok-kelompok lain yang berbeda basis identitasnya untuk menemukan kebutuhan bersama bagi sebuah integrasi.

Ekspresi atas etnisitas dan agama diatur secara ketat pada masa Orde Baru dengan berbagai regulasi dan gerakan politik yang menyebabkan terpendamnya berbagai rasa dendam, kekecewaan, dan diskriminasi. Pemerintah yang berkuasa pada saat itu memainkan peran sangat kuat dalam upaya memprioritaskan kebijakan negara, yaitu pertumbuhan ekonomi, dan mengabaikan pertumbuhan kultural. Akibatnya kemajuan ekonomi tidak dibarengi dengan fondasi kultural yang mapan. Kebijakan negara yang berorientasi pertumbuhan ekonomi tidak dirasakan secara merata. Karena itu, sikap antiminoritas sangat kental. Akibatnya, dinamika hubungan sosial menjadi sangat rentan akibat kebijakan negara dan tumbuhnya kelompok yang memainkan semangat agama dan etnisitas.

Persoalan etnisitas dan agama adalah persoalan kehidupan masyarakat, yang memiliki relasi-relasi atau hubungan-hubungan tertentu dalam struktur 
sosial. Hubungan etnisitas dan agama dengan struktur, sampai sekarang masih menjadi polemik, apakah etnisitas dan agama bagian dari struktur, entitas yang terpisah, atau bahkan etnisitas dan agama yang antara lain membentuk struktur sosial. Sering tersubordinasinya etnisitas dan agama ke dalam struktur menyebabkannya dipakai sebagai alat untuk menunjang struktur sosial yang telah ditetapkan oleh suatu grand design politik tertentu. Etnisitas dan agama tidak saja kehilangan otonominya, melainkan juga telah dimanipulasikan sedemikian rupa, sehingga menjadi sekadar alat legitimasi politik. Transformasi struktural ataupun transformasi etnik dan agama dapat menjadi tema pokok yang mengarahkan manusia atau masyarakat masuk ke dalam suatu keadaan yang memungkinkan terjadinya keadilan sosial atau perdamaian manusia.

Kompleksitas etnisitas dan agama dalam struktur sosial yang multikultural tidak hanya terlihat dari lingkupnya yang membesar menuju pada arus global, ${ }^{3}$ tetapi juga makin banyaknya satuan-satuan kecil yang tumbuh. Karena itu, desain besar etnisitas dan agama, di samping perlu menyelidiki hubungan-hubungan dengan aras global, juga perlu memberikan peluang, mengamati atau mengenali dan bersikap arif terhadap pertumbuhan satuan-satuan kecil. Menelantarkan interaksi antarsatuan-satuan kecil berarti membiarkan berlakunya hukum rimba di dalam kebudayaan. Darwinisme sosial akan menyebabkan involusi bagi sebagian besar kelompok etnik dan agama, namun kemajuan bagi sebagian kecil yang lain, dan ini sama artinya memandang manusia sebagai makhluk mekanik. Manusia adalah satusatunya makhluk yang mampu berencana, sehingga untuk maju tidak harus "membunuh" yang lain.

Dalam sebuah komunitas heterogen dan pluralistik seperti Indonesia diperlukan perekat interaksi sosial yang dipatuhi bersama, terutama ketergantungannya terhadap pertukaran

Karakteristik globalisasi adalah (1) membawa arus budaya global yang dikendalikan iklim kapitalisme dan neoliberalisme yang membawa kultur yang kekuatan dasarnya adalah kekuatan ekonomi dengan 'ekonomi uang' yang menggeser 'ekonomi produksi'. Hidup bersama yang dalam komunitas awal didasarkan atas kreasi olah alam menjadi produk dan hasil kerja budaya, bergeser dengan 'ekonomi uang' atau moneter yang melintasi batas kendali teritorial negara; (2) akibat mengglobalnya modal lintas batas negara, juga merupakan akibat perkembangan pesat pengetahuan dan informasi dengan teknologi informasinya. Teknologi informasi ini dicirikan oleh (a) pengetahuan dan informasi diproduksi bila dinilai efisien dan efektif, yang diukur dari kegunaan (Lyotard, 1984, 1979,); (b) informasi dan pengetahuan semakin diperlakukan sebagai komoditas yang ditentukan pasar. (reciprocitas) atau dengan bahasa Fukuyama (1995:222), "kepercayaan memiliki nilai pragmatis yang sangat penting. Kepercayaan adalah pelumas yang penting bagi bekerjanya sebuah sistem sosial." Kepercayaan merupakan variabel yang penting dalam membentuk masyarakat yang fungsional, karena di dalamnya terkandung harapan-harapan terhadap keteraturan, kejujuran, dan perilaku kooperatif yang muncul dari dalam sebuah komunitas yang didasarkan pada norma-norma yang dianut bersama. Oleh karena itu, sebagai sebuah komunitas etnisitas dan agama bergantung pada kepercayaan dan kepercayaan ditentukan secara kultural, maka komunitas spontan akan muncul dalam berbagai tingkatan berbeda dalam budaya yang berbeda pula. Bagi Fukuyama (2000:72) kepercayaan atau trust adalah efek samping yang penting dari norma-norma sosial kooperatif yang memunculkan modal sosial. Jika suatu komunitas dapat menjaga komitmen, menghormati normanorma saling tolong-menolong, dan menghindari perilaku yang oportunistik, maka berbagai kelompok akan terbentuk dengan cepat, dan kelompok ini akan mampu mencapai tujuan bersamanya secara lebih efisien.

Munculnya komunitas-komunitas kelompok etnik dan agama yang menempati lokasi tertentu dalam ruang kota merupakan satu dari banyak bukti kegagalan kebijakan negara dalam "mengatur" perubahan sosial. Munculnya komunitas kelompok etnik juga merupakan bukti adanya kegagalan asimilasi maupun akulturasi yang membuat setiap kelompok etnik cenderung memilih hidup dan berinteraksi dengan bahasa, adat istiadat dan normanya sendiri. Kesadaran etnik dan keagamaan mengacu pada acuan yang berlapis-lapis sesuai dengan kebutuhan para anggota kelompok etnik ketika melakukan interaksi. Terdapat dua perspektif yang berbeda mengenai menguatnya kesadaran etnik. Pertama, perspektif budaya (cultural perspective), yaitu kesadaran etnik sebagai hasil dari primordialisme, seperti adanya persepsi sempit dari anggota-anggota kelompok masyarakat tentang ciri-ciri kelompok mereka yang didasarkan pada unsur-unsur yang diwariskan yang berbeda dengan kelompok lainnya, seperti perbedaan kebahasaan, dan ketidaksesuaian dalam segi budaya (Alqadrie, 1990:26). Kedua, perspektif struktural yang menunjukkan asal-usul menguatnya kesadaran etnik yang berkaitan dengan hubungan kompetisi yang "tidak adil" antarkelompokkelompok masyarakat di dalam ekonomi politik dan bidang-bidang sosial ekonomi daripada dengan fakta pluralisme dan primodialisme (Alqadrie, 1990; Olubeni, 1983:265). 
Penelitian dilakukan di Kota Surabaya yang merupakan daerah dengan kelompok masyarakat yang beragam, baik dari pendidikan, status sosial, tingkat ekonomi, dan juga etnisitasnya. Penelitian dilakukan untuk melihat pemaknaan simbol, bahasa, dan etika pergaulan mereka dalam perspektif interaksionisme simbolik.

\section{Komunitas Etnik di Kota Surabaya}

Surabaya adalah kota multietnis, kota ini dihuni masyarakat dari berbagai daerah sehingga membentuk mozaik keindonesiaan yang unik. Etnis Jawa merupakan penghuni terbesar di kota Surabaya, disusul kemudian orang Madura. Orangorang Madura banyak tinggal di kota Surabaya karena kota ini kota terbesar yang paling dekat dengan pulau Madura. Etnis lain yang tinggal di kota Surabaya adalah orang Sunda, Sumatera, Kalimantan, Ambon, Bali, Tionghoa, Arab, Eropa, serta orang-orang berlatar belakang etnis yang amat beragam baik dari Indonesia maupun dari luar Indonesia. Menurut Basundoro (2012:1), keragaman etnis di Surabaya sudah terbentuk sangat lama. Hal tersebut disebabkan adanya gelombang migrasi dan urbanisasi dari berbagai tempat ke kota Surabaya.

Orang Jawa merupakan penghuni terbesar kota Surabaya karena kota ini berada di Jawa. Secara kultural pusat kebudayaan Jawa berada di Jawa Tengah dan Jawa Timur, dan di Jawa Timur sebagian besar orang Jawa tinggal di sepanjang pesisir utara serta di bagian tengah daerah ini. Orang-orang Jawa yang tinggal di kota Surabaya ada yang sejak awal memang memiliki nenek moyang yang lahir dan tinggal di kawasan tersebut selama ratusan tahun yang lalu, namun banyak pula yang mereka baru saja tinggal di kota Surabaya baru beberapa puluh tahun. Kategori kedua adalah para pendatang dari daerah lain yang datang ke kota tersebut untuk mencari penghidupan yang lebih baik. Bahkan pada sensus yang dilakukan oleh pemerintah kolonial Belanda pada tahun 1930 diketahui bahwa lebih dari 50 persen penduduk kota Surabaya pada waktu itu lahir di kabupaten-kabupaten di luar kota Surabaya, seperti Sidoarjo, Lamongan, Gresik, Mojokerto, Jombang, Tuban serta kabupaten-kabupaten lain di Jawa Timur (Basundoro, 2013: 94).

Sebagian besar daerah di Tuban, Lamongan, dan Gresik merupakan daerah tandus yang tidak bagus untuk ditanami tanaman pertanian, sehingga kehidupan masyarakat di daerah tersebut cukup sengsara. Untuk mengatasi problem ekonomi yang akut, penduduk setempat banyak yang merantau ke kota Surabaya. Etnis Madura merupakan penghuni terbanyak kedua di kota Surabaya. Surabaya merupakan kota besar terdekat dari Pulau
Madura, sehingga menjadi tujuan awal orangorang Madura yang ingin mencari penghidupan yang lebih baik. Kondisi Pulau Madura yang tandus dan kering menyebabkan sebagian besar penduduknya bermigrasi ke luar pulau. Menurut Kuntowijoyo tradisi bermigrasi orang-orang Madura sudah terjadi sejak ratusan tahun yang lalu (Kuntowijoyo, 2002: 75). Pada masa kerajaan Mataram sebagian pendatang dari Madura ada yang bergabung menjadi prajurit Mataram. Sejak akhir abad ke-19 sebagian besar pendatang dari Madura di Pulau Surabaya banyak yang bekerja sebagai buruh di pelabuhan Surabaya. Sejak kebijakan sistem tanam paksa diterapkan di Jawa, pelabuhan Surabaya berubah menjadi pelabuhan yang amat sibuk sebagai pelabuhan ekspor-impor. Kondisi tersebut memerlukan banyak sekali buruh angkut, dan orang-orang dari Madura memanfaatkan kesempatan tersebut. Menurut John Ingleson pada awal abad ke-20 jumlah buruh dari Madura di pelabuhan Surabaya berjumlah kurang lebih 10.000 orang (Ingleson, 2004:4). Keberadaan orang-orang Madura di kota Surabaya telah mempengaruhi budaya setempat, terutama mempengaruhi dialek Bahasa Jawa Suroboyoan.

Asal-susul orang Bali dan Lombok di Kota Surabaya kemungkinan besar berkaitan dengan perdagangan budak yang terjadi pada abad ke-18 sampai awal abad ke-19. Pada tahun 1839, di Kota Surabaya terdapat 1.506 budak yang dipekerjakan di keluarga-keluarga Eropa. Keluarga-keluarga tersebut mendapatkan budak dari pelelangan. Pada tahun 1850-an perdagangan budak di Kota Surabaya dilarang. Sebagian besar bekas budak kemudian menjadi orang bebas di kota tersebut (Faber, 1931: 63-64). Keberadaan orang-orang Maluku/Ambon di Kota Surabaya, sebagian besar adalah orangorang yang direkrut menjadi tentara KNIL oleh pemerintah kolonial Belanda, dan sebagian kecil adalah orang-orang bebas yang merantau ke Kota Surabaya atas kemauan sendiri (Sugiarti, 2009). Di Kota Surabaya sebagian orang-orang Bali tinggal di Kampung Peneleh. Salah satu ruas jalan di kamoung tersebut identik dengan etnis Bali.

Orang-orang Sumatera juga banyak datang di Kota Surabaya. Salah satu roman yang sangat terkenal yang berjudul Tenggelamnya Kapal van der Wijck menceritakan bahwa pada tahun 1930an di Kota Surabaya terdapat perkumulan orangorang dari Sumatera, terutama dari Minangkabau. Roman tersebut menceritakan bahwa saat-saat tertentu orang-orang yang berasal dari Sumatera berkumpul untuk merayakan hari-hari besar tertentu (Hamka, 1984). Keberadaan orang-orang Sumatera tersebut telah membentuk pemukiman di 
sebelah selatan kawasan masjid Ampel yang oleh pemerintah kolonial Belanda dimasukan sebagai sebuah kawasan tersendiri yang disebut Maleische Kamp atau Kampung Melayu. Beberapa tokoh masyarakat Melayu di Kota Surabaya telah terlibat dalam pemerintahan sejak masa kolonial, bahkan Walikota Surabaya pertama di awal kemerdekaan, yaitu Radjamin Nasution, merupakan salah satu tokoh masyarakat Melayu di Kota Surabaya.

Para pendatang dari Sulawesi di Kota Surabaya sebagian adalah para pelaut yang kemudian memilih menetap di kota ini dan sebagian lagi adalah orangorang yang sengaja merantau untuk mencari penghidupan. Ada pula orang yang datang ke kota Surabaya untuk menuntut ilmu. Pada awal abad ke-20 lembaga pendidikan modern sudah berdiri di kota Surabaya dan menjadi tempat menuntut ilmu orang-orang dari luar kota. Beberapa pelajar yang belajar di Kota Surabaya dan akhirnya menetap di kota ini adalah J.K. Lengkong, S. Ngion, dan F.L.S. Ratulangi, yang pada awal tahun 1930 diangkat sebagai anggota Gemeenteraad Surabaya (Gemeente Soerabaja, 1931: 35).

Selain dihuni oleh para endatang dari berbagai pulau di Indonesia, kota Surabaya juga dihuni oleh pendatang dari luar negeri. Sudah sejak lama para pendatang dari luar negeri menetap di kota Surabaya, salah satunya karena alasan berdagang. Orang-orang Arab merupakan salah satu pendatang dari luar negeri yang cukup banyak. Mereka menetap di kampung sekitar makam tokoh penyebar Islam di kota Surabaya, Sunan Ampel. Gelombang kedatangan orang-orang Arab sudah terjadi sejak sebelum Indonesia dijajah Belanda, namun mengalami peningkatan yang luar biasa sejak abad ke-19. Mereka kemudian menetap dan membantuk perkampungan Arab di sekitar masjid Ampel yang pada masa colonial diberi nama Arabische Kamp atau Kampung Arab. Nenek moyang orang-orang Tionghoa sudah mendiami kota Surabaya sudah sejak sangat lama. Ketika orang-orang Belanda yang datang di kota Surabaya pada abad ke-17, mereka sudah melihat pemukiman-pemukiman Tionghoa di tepi sungai Kalimas (Basundoro: 2013). Mereka membentuk pemukiman Tionghoa yang pada masa kolonial disebut Chinese Kamp (kampung Cina atau Pecinan) dan berkembang sampai saat ini, menjadi pusat perdagangan di kota Surabaya. Sementara itu, akar kedatangan orang-orang Eropa berbarengan dengan penjajahan Belanda di Indonesia, yaitu sekitar abad ke-17.

Dengan banyaknya orang dari berbagai daerah, dari berbagai pulau, dan dari berbagai negara yang datang dan tinggal di kota Surabaya, menjadikan kota ini sebagai kota multikultural.
Mereka membawa berbagai unsur kebudayaan masing-masing yang kemudian berkembang di kota Surabaya. Ada unsur-unsur kebudayaan yang saling menyatu dan saling mempengaruhi, ada pula unsurunsur kebudayaan yang berkembang sesuai aslinya.

\section{Dinamika Interaksi Antaretnik dan Agama di Kota Surabaya}

Kehadiran para pendatang di Surabaya, memperlihatkan potret masyarakat majemuk atau bhinneka tunggal ika, yaitu sebuah masyarakat yang terdiri atas masyarakat-masyarakat sukubangsa yang dipersatukan dan diatur oleh sistem pemerintahan daerah. Seperti halnya masyarakat Indonesia pada umumnya, setiap masyarakat sukubangsa di Surabaya secara turun temurun mempunyai dan menempati wilayah tempat hidupnya yang diakui dan dihormati yang merupakan tempat sumber-sumber daya dimana warga masyarakat sukubangsa tersebut memanfaatkan untuk kelangsungan hidup mereka.

Di Kota Surabaya, masyarakat majemuknya bukan hanya beranekaragam corak kesukubangsaan dan kebudayaannya secara horizontal, tetapi juga secara vertikal, yaitu menurut kemajuan ekonomi, teknologi, dan organisasi sosial-politiknya (Suparlan, 2004). Tanpa disadari oleh banyak orang Indonesia, sebenarnya dalam masyarakat terdapat golongan dominan dan minoritas, sebagaimana yang terwujud dalam tindakan-tindakan yang dilakukan terhadap mereka dalam berbagai interaksi, baik interaksi secara individual maupun secara kategorikal, seperti posisi orang Sakai yang minoritas dibandingkan dengan posisi orang Melayu yang dominan di Riau (Suparlan, 2008).

Dampaknya, kesukubangsaan atau jatidiri sukubangsa sebagai sebuah kekuatan sosial yang tidak bisa ditawar, yang muncul dalam interaksi sosial, menjadi sebuah acuan yang ampuh dalam upaya kohesi sosial dan solidaritas di antara sesama anggota sukubangsa dalam persaingan dan perebutan sumber-sumber daya yang secara adat menjadi hak mereka. Dalam setiap interaksi, jatidiri akan nampak karena adanya atribut-atribut yang digunakan oleh pelaku dalam mengekspresikan jatidirinya sesuai dengan hubungan status atau posisi masing-masing (Suparlan, 2008). Dalam hubungan antar-sukubangsa yang terjadi di Kota Surabaya tidak terjadi manifestasi atribut dari jatidiri sukubangsa, yaitu ciri-ciri fisik atau rasial, gerakan-gerakan tubuh atau muka, dan ungkapan-ungkapan kebudayaan, nilai-nilai budaya serta keyakinan keagamaan menjadi sesuatu yang membedakan. Sadar atau tidak sadar seseorang hidup berpedomankan pada kebudayaan 
sukubangsanya, yang dalam proses-proses pembelajarannya dari masa anak-anak sehingga dewasa, dia tidak mempunyai pilihan lain kecuali harus hidup menurut kebudayaan sukubangsanya yang dipunyai oleh orang tuanya tersebut.

Setiap anggota komunitas harus tahu, memahami, dan meyakini, serta menggunakan kebudayaan tersebut sebagai pedoman bagi kehidupannya dalam menghadapi dan menginterpretasi lingkungannya, dan untuk dapat memanfaatkan berbagai sumber daya yang ada di dalamnya bagi kelangsungan hidupnya. Jika hal ini dapat dianggap sebagai salah satu stereotype kesukubangsaan, maka kebudayaan sukubangsa, bagi anggota-anggota sukubangsa yang bersangkutan, adalah sebuah pedoman bagi kehidupan yang pertama dipelajari dan diyakini kebenarannya.

Selain itu, yang juga bercorak 'dipaksakan' adalah pelajaran agama dari orang tua, keluarga, dan komunitas sukubangsa tersebut sehingga jika seseorang beragama Islam, maka Islamlah keturunannya sampai hari ini. Agama dinilai sebagai teks suci yang berisikan petunjuk-petunjuk Tuhan yang wajib diikuti, yang sebaiknya dihindari, dan yang wajib dihindari atau dilarang untuk dilakukan menjadi operasional dalam kehidupan manusia melalui dan ada dalam kebudayaan manusia dan pranata-pranata sosial masyarakatnya. Petunjukpetunjuk Tuhan ini diinterpretasi dan dipahami dengan menggunakan acuan kebudayaannya, untuk dijadikan sebagai pedoman bagi kehidupan yang tidak bertentangan dengan kebudayaan yang sudah ada, atau sebaliknya yaitu sebagian atau sebagian besar nilai-nilai budaya yang sudah ada itu disesuaikan dengan nilai-nilai keagamaan yang diyakini kebenarannya. Agama sebagai teks suci yang berisikan nilai-nilai sakral biasanya menggantikan sebagian atau seluruh nilai-nilai budaya yang menjadi inti dan yang mengintegrasikan keutuhan dari sesuatu kebudayaan sukubangsa.

Konflik yang muncul secara langsung meruntuhkan kepercayaan dalam ruang lingkup batas-batas kesukubangsaaan ini sehingga stereotip dan prasangka berkembang dan menjadi mantap dalam suatu kurun waktu hubungan antar-sukubangsa dalam empat tahun terakhir. Akibatnya banyak saling salah pengertian di dalam komunikasi antar-sukubangsa, terutama simbol-simbol keagamaan atau simbol-simbol etnis yang menyebabkan semakin lebarnya jarak dan mantapnya batas-batas atau pagar-pagar yang membatasi hubungan antara dua sukubangsa atau lebih. Akibat lebih lanjut, jika tidak segera diatasi dari stereotip dan prasangka ini dapat mewujudkan tindakan-tindakan diskriminatif dalam hak dan kewajiban oleh sukubangsa yang dominan terhadap mereka yang tergolong lemah dan nonpribumi atau minoritas di dalam kehidupan sosial, politik, dan ekonomi.

Dari satu segi, kesukubangsaan sebagai kekuatan sosial mirip dengan keyakinan keagamaan. Karena keyakinan keagamaan pada waktu terwujud sebagai sebuah solidaritas sosial juga tidak dapat ditawar atau diremehkan. Kedua-duanya mempunyai potensi merusak yang sama besarnya di dalam konflik antarsukubangsa atau antarkeyakinan keagamaan. Tetapi dari segi lain, kesukubangsaan dan keyakinan keagamaan tidaklah sama. Karena kesukubangsaan mempunyai efektivitas kekuatan sosial dalam batas-batas sesama anggota sukubangsa, sedangkan keyakinan keagamaan mempunyai jangkauan solidaritas sosial hanya dalam salah satu segmen masyarakat sukubangsa, dalam sesuatu masyarakat sukubangsa, atau di luar batasbatas sesuatu masyarakat sukubangsa. Karena itu, di satu sisi, keyakinan keagamaan dapat memperkuat atau memperlemah kekuatan sosial dari kesukubangsaan, sedangkan di sisi lain kesukubangsaan dapat tunduk dan berada di bawah bayang-bayang kekuatan keyakinan keagamaan.

Di masa lampau hanya di kota-kota besar terdapat kehidupan masyarakat yang kesukubangsaannya beranekaragam. Tetapi pada masa sekarang hampir seluruh wilayah Indonesia secara sukubangsa adalah heterogen, dimana anggota-anggota sukubangsa dari berbagai sukubangsa dan daerah yang berbeda-beda telah secara berdampingan hidup dalam komunitikomuniti dari kelompok-kelompok sukubangsa setempat. Sehingga hubungan antar-sukubangsa menjadi lebih intensif daripada di masa lampau, dan hal ini dapat menyebabkan berbagai permasalahan berkenaan dengan pengakomodasian perbedaanperbedaan budaya antara pendatang dengan penduduk setempat karena hampir semua pendatang yang hidup di komuniti-komuniti setempat mempunyai kebudayaan ekonomi yang lebih maju dan lebih agresif. Permasalahan hubungan antara pendatang dengan masyarakat setempat terpusat pada masalah kompetisi untuk memperebutkan sumbersumber daya. Tingkat agresivitas secara ekonomi dari para pendatang adalah masalah yang paling kritikal dalam persaingan untuk memperebutkan sumber-sumber daya yang ada. Karena, masyarakat setempat melihat diri mereka sebagai tuan rumah serta pemilik atas sumber-sumber daya alam yang ada di dalam wilayah hak ulayat mereka sedangkan para pendatang dilihat sebagai tamu mereka.

Sebagai unsur pembentuk sistem sosial masyarakat majemuk, kelompok-kelompok etnik memiliki kebudayaan, batas-batas sosial-budaya, dan 
sejumlah atribut atau ciri-ciri budaya yang menandai identitas dan eksistensi mereka. Kebudayaan yang dimiliki kelompok etnik menjadi pedoman kehidupan mereka dan atribut-atribut budaya yang ada, seperti adat-istiadat, tradisi, bahasa, kesenian, agama dan paham keagamaan, kesamaan leluhur, asal-usul daerah, sejarah sosial, pakaian tradisional, atau aliran ideologi politik menjadi ciri pembeda suatu kelompok etnik dari kelompok etnik yang lain. Kebudayaan dan atribut sosial-budaya sebagai penanda identitas kelompok etnik memiliki sifat stabil, konsisten, dan bertahan lama.

Dalam kasus Kota Surabaya, misalnya orang Jawa disebut sebagai suatu kelompok etnik karena mereka secara budaya memang berbeda dengan orang Madura. Dalam konteks perbandingan yang setara pada orang Jawa di Jawa Timur, bahwa orang Jember tentu berbeda secara kultural dengan orang Surabaya. Orang Jember tidak akan mau disebut sebagai orang Surabaya, demikian pula sebaliknya. Karena perbedaan-perbedaan kultural ini keduanya disebut sebagai sebuah kelompok etnik yang berbeda, walaupun keduanya berada dalam ruang lingkup orang Jawa, di Jawa Timur. Hal yang sama juga berlaku untuk penyebutan orang Osing, orang Tengger, orang Pendhalungan, orang Mataraman, atau orang Samin sebagai sebuah kelompok etnik yang berbeda-beda.

Dalam kaitannya dengan akses dan perebutan sumber daya di daerah yang bersifat struktural, seperti potensi ekonomi dan kekuasaan politik, manifestasi etnisitas sering menimbulkan ketegangan dan konflik sosial di antara pihakpihak yang terlibat atau yang berkepentingan. Masa otonomi daerah sekarang ini memberikan peluang yang besar bagi tumbuhnya konflik sosial berbasis etnisitas, ketika tradisi berdemokrasi, penghormatan terhadap keadilan sosial, dan penghargaan terhadap prestasi belum menjadi pandangan dan sikap hidup kita sehari-hari. Kondisi demikian lebih banyak menguntungkan kepentingan pribadi dan kelompok (etnik) daripada kepentingan masyarakat. Masalahnya adalah bagaimanakah meminimalkan konflik sosial berbasis etnisitas yang dapat merugikan kepentingan masyarakat luas.

Secara normatif, otonomi daerah telah memberikan keleluasaan bagi masyarakat di daerah (bukan pemerintah daerah) untuk mengaktualisasikan diri secara optimal dalam manajemen pembangunan daerah. Undang-undang yang mendasari praktik otonomi daerah memberi pengakuan terhadap eksistensi masyarakat dan kebudayaannya. Otonomi daerah menandai era penghargaan terhadap keberagaman dan otonomi masyarakat, setelah Orde Baru memberangusnya selama masa tiga dasawarsa lebih (Zakaria, 2000). Dalam ruang politik yang semakin terbuka ini, masyarakat di daerah (indigenous people) menggali kembali potensi-potensi kelembagaan sosial atau konstruk nilai-nilai budaya lokal yang dianggap berguna untuk menopang eksistensi mereka di tengah arus globalisasi dan dinamika pembangunan daerah.

Keberlangsungan hubungan sosial tersebut memiliki prasyarat yang harus dipenuhi. Lawrence Harrison, seperti dikutip oleh Francis Fukuyama (1995), menjelaskan kemungkinan terbatasnya daya kerja modal sosial melalui konsep radius of trust atau radius kepercayaan, yaitu lingkaran manusia tempat norma-norma kerjasama berlaku. Konsep ini membatasi berlakunya modal sosial di kalangan pendukungnya saja, sehingga apabila radius kepercayaan suatu modal sosial kecil, maka keberlakuan modal sosial itu untuk mendukung tercapainya hubungan sosial yang fungsional, menjadi kecil, atau hanya berlaku di dalam kelompok tertentu saja. Bahkan, radius yang sangat kecil akan menciptakan banyak sekali penentangan dari dan terhadap orang-orang di luar lingkaran modal sosial.

Syarat pertama dari hubungan yang positif adalah besarnya radius kepercayaan sehingga modal sosial tidak menjadi kontraproduktif. Syarat kedua berkaitan dengan sifat otonom dan kemelekatannya pada masyarakat yang berlaku bagi individu-individu pendukung modal sosial tertentu. Otonomi yang berlebihan pada individu akan membuat keberlakuan norma serta jaringan menjadi kecil, sementara itu kemelekatan yang berlebihan juga akan membawa pendukung modal sosial tertentu menjadi tidak kreatif. Dalam bahasa yang berbeda, bila sejumlah orang mengelompok atas dasar suku bangsa atau agama, akan menimbulkan kategorisasi secara sosial (social categorization, Abrams dan Hogg, 1990). Kategori sosial ini merupakan dasar dari pembentukan kelompok "kita" (ingroup) dan kelompok "mereka" (outgroup) (Tajfel,1982). Atau dengan perkataan lain, kombinasi yang optimum antara otonomi dengan kemelekatan menciptakan hubungan sosial kongkret yang sedang berlangsung. Ini berarti, bahwa aktor mendefinisikan situasi sosialnya terlebih dahulu, sebelum menanggapi orang lain. Atau dengan perkataan lain, memahami modal sosial memperlihatkan, bahwa tindakan disituasikan secara sosial dan melekat dalam jaringan hubungan sosial personal yang sedang berlangsung dari para aktor.

Persoalannya adalah bahwa dewasa ini hubungan positif bagi berlakunya kepercayaan yang lebih luas mulai memudar, karena setelah terbentuk kelompok "kita" dan kelompok "mereka" cenderung 
terjadi permusuhan dan memperkecil perdamaian sosial. Fenomena kekerasan yang terjadi, praktis setelah krisis ekonomi terjadi, merupakan bentuk nyata tidak adanya perdamaian sosial. Dalam wacana ilmu sosial, menurut Ignas Kleden (2001) kekerasan mempunyai suatu struktur-dalam (deep structure) yang tersembunyi dalam berbagai bidang kebudayaan dan kehidupan masyarakat Indonesia dewasa ini, yang kemudian memperlihatkan diri dalam berbagai ekspresi yang berbeda-beda, tetapi pada dasarnya menyembunyikan struktur dasar yang kurang lebih sama.

Para ahli kependudukan dan budaya perkotaan sering menyebut bahwa kota adalah melting pot atau panci pelebur dimana orang dari berbagai macam etnis dan bangsa melebur menjadi satu (Castles, 2007:2). Namun, kenyataan kota pada masa kolonial bukanlah panci pelebur dalam arti yang sebenarnya. Keberadaan orang Eropa di kota-kota besar di Indonesia telah menciptakan masyarakat yang berlapis-lapis yang dibedakan berdasarkan etnis secara ketat. Golongan paling utama adalah orang Belanda Totok yang beragama Kristen. Di bawah Belanda Totok adalah Belanda Indo, dan di bawah Belanda Indo adalah orang Cina, Arab, dan Timur Asing. Lapisan paling bawah adalah orang Indonesia (Bumiputra) (Suryohadiprojo, 1997:8).

Hubungan antaretnik di Kota Surabaya, terutama hubungan antara orang-orang keturunan Cina dan Arab dengan penduduk lokal cukup unik. Hubungan semacam ini bisa berlainan yang kadangkadang dilandasai oleh motivasi kemanusiaan, yaitu hubungan yang murni berdasarkan status sosial yang tidak dilandasi sentiman rasial. Jika hubungan tersebut terjalin antara majikan yang Cina atau Arab dan buruh yang Indonesia, maka baik-buruknya hubungan tersebut hanya bisa dinilai dari kelas sosial mereka yang berbeda dan bukan karena perbedaan ras di antara mereka. Pada kenyataannya, kedudukan kaum buruh Indonesia di perkebunan-perkebunan, kantor-kantor, dan pabrik-pabrik sangat lemah yang disebabkan karena daya tawar mereka amat rendah sebagai akibat rendahnya pendidikan.

Dalam hubungan antaretnis di Surabaya tidak terlihat adanya penguasa daerah untuk mencapai penguasaan sumber daya ekonomi-politik yang lebih besar dengan mendominasi etnik tertentu. Demikian pula dengan penetrasi budaya dominan (dominance culture), terhadap etnis minoritas tidak bersifat deskriminatif dan hanya menguras sumber daya lokal. Dalam studi-studi konflik etnik, kebijakan politik etnik negara memperluas batas-batas sosial budaya identitas suatu kelompok etnik, khususnya etnik yang dianggap kelompok dominan, yang senantiasa berhadapan dengan penolakan atau resistensi sosial dari kelompokkelompok etnik yang terkena kebijakan tersebut. Sementara itu, jika terjadi konflik, setiap kelompok etnis akan mengaktifkan jaringan etnisitas yang berbasis kesamaan asal-usul dan leluhur, sejarah sosial, identitas ke-Islam-an, dan tradisi sosialbudaya sebagai sarana pengikat sosial dan pembangun solidaritas sosial. Dalam konteks demikian, etnisitas akan berubah menjadi ideologi perjuangan untuk menghadapi etnis lain yang telah membuat diri mereka tidak nyaman dan terancam serta mengganggu kelangsungan hidup kelompok etnik (Brown, 1994:1-5).

Dalam banyak kasus, negara dan kebijakankebijakan para penguasanya mengambil peranan yang besar terhadap timbulnya peristiwa konflik etnik dan kekerasan sosial di berbagai negara (Renner, 1999:33-47). Konflik-konflik dan kekerasan sosial berbasis etnisitas yang terjadi di Indonesia menjelang akhir kekuasaan Orde Baru hingga sekarang, seperti di Kalimantan BaratTengah, Maluku, dan Poso merupakan akibat dari kesalahan kebijakan pembangunan daerah dan ketidakmampuan penguasa Orde Baru mengelola kemajemukan masyarakat kita (Kusnadi, 2001). Hal yang sama bukan tidak mungkin akan dilakukan oleh penguasa Pemerintah Daerah (eksekutif dan legislatif) era otonomi daerah. Bahkan, diperkirakan bahwa sifat rakus politik dan serakah ekonomi penguasa di daerah dan kebijakan-kebijakannya yang tidak memihak kepentingan rakyat akan menjadi pemicu konflik sosial yang berskala luas di daerah. Konflik sosial ini tidak hanya terjadi di kalangan internal antarelite daerah, tetapi juga melibatkan penguasa daerah dengan rakyat secara keseluruhan dan antarkelompok-kelompok sosial dalam masyarakat. Ketidakpuasan rakyat yang meluas terhadap perilaku pemimpinnya dapat mendorong timbulnya revolusi sosial, sebagaimana pernah terjadi dalam sejarah sosial kita (Lucas, 2004).

Pada dasarnya, konflik sosial berbasis etnisitas yang berlangsung secara masif tidak ada yang semata-mata terjadi karena perbedaan-perbedaan sosial-budaya yang bersifat horisontal, seperti agama, bahasa, tradisi dan adat-istiadat, sejarah sosial, gaya hidup, atau nilai-nilai budaya lainnya. Aspek-aspek vertikal-struktural, seperti akses dan penguasaan sumber daya ekonomi-politik (kekuasaan) senantiasa terlibat. Bahkan semakin tinggi nilai sumber daya yang diperebutkan dan kondisinya terbatas, maka konflik sosial yang terjadi akan semakin intensif dan keras (Kusnadi dan Burhanuddin, 1997). Dalam situasi 
demikian, dampak konflik secara psikologis sangat mencekam masyarakat dan secara sosialekonomi memberatkan masa depan kehidupan mereka yang terlibat konflik. Upaya untuk meretas jalan menuju perdamaian abadi juga sangat sulit karena membutuhkan kesabaran, keseriusan, dan pengorbanan yang besar.

Oleh karena itu, bagaimanapun perlu dilakukan upaya untuk meminimalisasi timbulnya konflik-konflik sosial yang berbasis etnisitas, dengan jalan merumuskan kebijakan pembangunan dan pembuatan regulasi daerah yang bersifat transparan, demokratis, berorientasi kerakyatan, dan berdimensi keadilan sosial. Sementara itu, pada tataran sosial, dengan berbagai cara, penguatan kapasitas masyarakat harus dilakukan dengan membangun fondasi kesadaran strukturalkultural bernegara dan berbangsa agar memiliki kemampuan dalam berdikusi dengan elite daerah untuk memberi arah pada kebijakan pembangunan daerah yang memihak kepentingan masyarakat luas. Otonomi daerah harus ditafsirkan sebagai otonomi masyarakat untuk membangun daerahnya, bukan otonomi pemerintah daerah, karena esensi pemerintah daerah hanya sebagai alat pembangunan daerah. Di tengah-tengah karakter rezim otonomi daerah yang masih belum beradab, jalan untuk membangun fondasi kesadaran struktural-kultural di atas masih sangat panjang. Perjuangan memang tidak pernah selesai.

\section{Penutup}

Kota adalah melting pot atau panci pelebur dimana orang dari berbagai macam etnis dan agama melebur menjadi satu, antara keturunan Eropa, Cina, Arab dan Etnis Indonesia, seperti Melayu, Jawa, Madura, Ambon, Minangkabau, dan sebagainya. Jika terjadi konflik, karakteristik kelompok-kelompok yang berkonflik dapat dibedakan dalam dua hal, yaitu (1) kejelasan batasbatas antara kelompok-kelompok yang berkonflik, dan (2) derajat pengorganisasian masingmasing kelompok. Batas-batas kelompok yang berkonflik erat kaitannya dengan pola interaksi dan komunikasi yang dikembangkan dari dua belah pihak, kehidupan anggota setiap kelompok yang banyak dipengaruhi oleh komitmen anggota kelompoknya. Oleh karena itu, konflik sosial selalu melibatkan banyak pihak, maka analisis terhadap suatu konflik juga tidak terlepas dari keseluruhan hubungan antara kelompok-kelompok yang berkonflik

Budaya masyarakat dan agama yang berbeda cenderung akan berbenturan apabila masingmasing kelompok etnik mempertahankan batas etnik kelompoknya secara ketat. Interaksi sosial di Kota Surabaya lebih terbuka dan saling dapat memahami. Perbedaan budaya antara satu kelompok dengan kelompok etnik lainnya terwujud atau dapat ditemukan antara lain dalam bentuk sistem nilai budaya (cultural value system) dan orientasi nilai budaya (cultural value orientation). Perbedaan ini menjadi nyata pada saat sistem nilai budaya dan orientasi nilai budaya tersebut terjelma ke dalam sikap, mentalitas, perilaku dan perbuatan individu atau masyarakat sebagai warga dari kelompok etnik tempat mereka menjadi anggotanya. Persoalannya adalah bahwa dewasa ini hubungan positif bagi berlakunya kepercayaan yang lebih luas mulai memudar, karena setelah terbentuk kelompok "kita" dan kelompok "mereka" cenderung terjadi permusuhan dan memperkecil perdamaian sosial

Pada akhirnya, interaksi sosial di dalam kehidupan bermasyarakat di Kota Surabaya memperlihatkan bahwa setiap aktor yang berinteraksi memberikan pengakuan kepada kelompok-kelompok etnik dan agama lainnya dengan memposisikan dirinya ke dalam sebuah kehidupan bersama yang memiliki kesanggupan untuk memelihara identitas kelompoknya. Disamping itu, juga mampu berinteraksi dalam ruang bersama yang ditandai oleh kesediaan untuk menerima kelompok-kelompok lain yang berbeda basis identitasnya untuk menemukan kebutuhan bersama bagi sebuah integrasi. 


\section{DAFTAR PUSTAKA}

\section{Buku}

Abdilah, Ubed. 2002. Politik Identitas Etnis: Pergulatan Tanda Tanpa Identitas. Magelang: Indonesatera.

Ahfud, Choirul. 2010. Pendidikan Multikultural. Yogyakarta: Pustaka Pelajar.

Anwar, M. Syafi'i. 2006. “Islam dan Tantangan Pluralisme di Indonesia." Makalah. Semarang: IAIN Walisongo.

Azra, Azyumardi. 1999. Menuju Masyarakat Madani: Gagasan, Fakta, dan Tantangan. Cetakan I. Bandung: PT Remaja Rosda Karya.

Barker, Chris. 2000. Cultural Studies: Theory and Practice. London: Sage Publications Ltd.

Budiwanti, Erni. 2000. Islam Sasak: Wetu Telu versus Waktu Lima.Yogyakarta: LKIS.

Chris Mitchell. 1981. The Structure of International Conflict. London: Macmillan.

Coward, Harold. 1996. Pluralisme: Tantangan bagi AgamaAgama. terj. Tim Kanisius. Yogyakarta: Kanisius.

Dean, Tjosvold. 1982. The Conflict Positive Organization: Stimulate Diversity and Create Unity. Addison Wesley.

Fenton, Steve. 1999. Ethnicity: Racism, Class, and Culture, Lanham. Boulde. New York: Rowman \& Littlefield Publishers, INC.

Fisher, et.al. 2001. Mengelola Konflik: Keterampilan dan Strategi untuk Bertindak. Jakarta: The British Council.

Giddens, Anthony. 1994. Beyond Left and Right: The Future of Radical Politics. Cambridge: Polity Press.

Gurr, T. Robert. 1996. Minorities at Risk, Global View of Ethnopolitical Conflict. United State of Peace Press.

Hall, S. 1992. The Question of Cultural Identity. Cambridge: Polity Press.

Hall, S. 1996. New Etnicities, dalam D Morley and D.K. Chen (ed.). Stuart Hall. London: Routledge.

Heynes, Jeff. 2000. Demokrasi dan Masyarakat Sipil di Dunia Ketiga: Gerakan Politik Baru Kaum Terpinggir. Jakarta: Yayasan Obor Indonesia
Lijpart, Arend. 1977. Democracy in Plural Societies, a Comparative Exploration. Yale University Press.

Liliweri, Alo. 2001. Gatra-gatra Komunikasi AntarBudaya. Yogyakarta: Pustaka Pelajar.

Liliweri, Alo. 2005. Prasangka dan Konflik. Yogyakarta: LKIS.

Montagu, Ashley. 1988. The Cultured Man. New York: Permabooks.

Prayitno, Ujianto Singgih. 2011, Landasan Sosiologi dalam Perancangan Peraturan PerundangUndangan, Jakarta: P3DI Setjen DPR RI.

Ritzer, George, Douglas J. Goodman. 2004. Sociological Theory. New York: McGraw-Hill.

Rogers, Mary F. (ed). 1996. Multicultural Experience, Multicultural Theories. New York: McGraw-Hill.

Shihab, Alwi, 1997. Islam Inklusif Menuju Sikap Terbuka dalam Beragama. Bandung: Mizan.

Soeprapto, Ryadi. 2000. Interaksionisme Simbolik, Perspektiof Sosiologi Modern. Malang: Averroes Press dan Pustaka Pelajar.

Sofyan, Muhammad. 1999. Agama dan Kekerasan dalam Bingkai Reformasi. Yogyakarta: Penerbit Media Pressindo.

Sunarto, Kamanto. 2004. Pengantar Sosiologi, Jakarta: Lembaga Penerbit Fakultas Ekonomi Universitas Indonesia.

Suparlan, Parsudi. 2008. Dari Masyarakat Majemuk menuju Masyarakat Multikultural, Jakarta: Yayasan Pengembangan Kajian Ilmu Kepolisian.

Tajib, H. Abdullah. 1995. Sejarah Bima Dana Mbojo. Jakarta: PT Harapan Masa PGRI.

Week, J. 1990. The Value of Difference, dalam J. Rutherford (ed.) Identity: Community, Culture, Difference. London: Lawrence \& Wishart.

Zakaria, Fathurrahman. 1998. Mozaik Budaya Orang Mataram. Mataram: Yayasan Sumurmas Al-Hamidi.

\section{Dokumen}

Naskah Akademik Rancangan Undang-Undang tentang Kebudayaan, Biro Perancangan Undang-undang (PUU) Bidang Polhukam Kesra Sekretariat Jenderal DPR RI Tahun 2009. 